UDC 61

\title{
IN VITRO AND IN VIVO EFFECTS OF RADIO- FREQUENCY ELECTROMAGNETIC FIELDS
}

\author{
Begimbetova D. A ${ }^{1}$, Baiskhanova D. $M^{1}$, Matkarimov B. $T^{2}$, Shulgau Z. T . \\ ${ }^{1}$ Laboratory of Translational Medicine and Life Sciences Technologies, National \\ Laboratory Astana, Nazarbayev University \\ 53, Kabanbay batyr ave., Nur-Sultan, 010000, Kazakhstan \\ ${ }^{2}$ Laboratory of Biosensors and Bioinstruments, National Laboratory Astana, Nazarbayev \\ University \\ 53, Kabanbay batyr ave., Nur-Sultan, 010000, Kazakhstan \\ ${ }^{3}$ Laboratory of Toxicology and Pharmacology, National Center for Biotechnology, \\ Korgalzhyn road, 13/5, Nur-Sultan, 010000, Kazakhstan \\ d.baiskhanova@nu.edu.kz
}

\begin{abstract}
In recent years, there has been a massive distribution of mobile phones and Wi-Fi networks. In this regard, concerns about their potential effects on living organisms, including humans, are increasing. Despite earlier assumptions about the absence of harmful effects of short-term exposure to radio frequency electromagnetic fields emitted by mobile phones and Wi-Fi networks, there is now increasing evidence of the potentially harmful effects of electromagnetic fields on the human body through the induction of oxidative stress and damage to DNA structure. It is assumed that prolonged exposure to electromagnetic fields can cause the development of various pathological conditions in the human body, including oncological diseases, impaired cognitive functions and sleep, etc.

This review analyzes and summarizes existing studies indicating various negative effects of radio frequency electromagnetic fields on human and animal cells. Since there is a large amount of conflicting data on the effect of electromagnetic fields on the human body, only further research can provide an answer to the possible negative effects of mobile phones and Wi-Fi networks usage.

Key words: electromagnetic field, effects, in vitro, in vivo, radio frequency, apoptosis, DNA damage.

\section{INTRODUCTION}

With the growth of globalization, the world began to change with great speed, increasing the pace of development and change. With the rapid increase in population and energy consumption, wireless and telecommunication technologies have also spread rapidly, which in turn have led to environmental pollution, posing a threat to the health of the world's population as well as to its biodiversity. Currently, the widespread use of electronic devices, electromagnetic fields (EMFs) have become a global phenomenon that generates a large number of controversies in the scientific world and worries the world's population.

EMF consists of electric and magnetic fields, and its discovery took place in the 19th century, when electromagnetic radiation from natural sources was discovered. In addition to natural sources of EMF, humans are also exposed to artificial EMF, such as mobile phones, wireless Wi-Fi networks, base stations of mobile operators, radio stations, computer and
\end{abstract}


television screens, and many other sources of artificially created EMF, widely used by people in their everyday life.

The issue of EMF safety or harm is a root of many discussions. These discussions encourage research conducted on safety or harm of permanent EMF on humans. A number of studies carried out on animals and cells have shown the effect of EM radiation on them and on the functional properties of cells, but the results remain preliminary. There are also studies that have shown the therapeutic potential of EMFs on various organs and systems, including the reversibility of cognitive impairment in Alzheimer's disease, stimulation of regenerative processes in bones and cartilage, wound healing, and regeneration of nerve tissues.

The aim of this review is to analyze and summarize the available studies that describe the effect of radio frequency (RF) EMF on cells and animals.

In vitro effects of EMF. Interest in the effects of RF exposure on the human body has grown in parallel with the massive spread of technology. It is assumed that radiation from radiofrequency EMF have a negative impact on mammalian cells (figure 1), causing oxidative stress, damage to DNA molecules, including changes in the expression of protein level and lipid peroxidation in human cell lines [1].

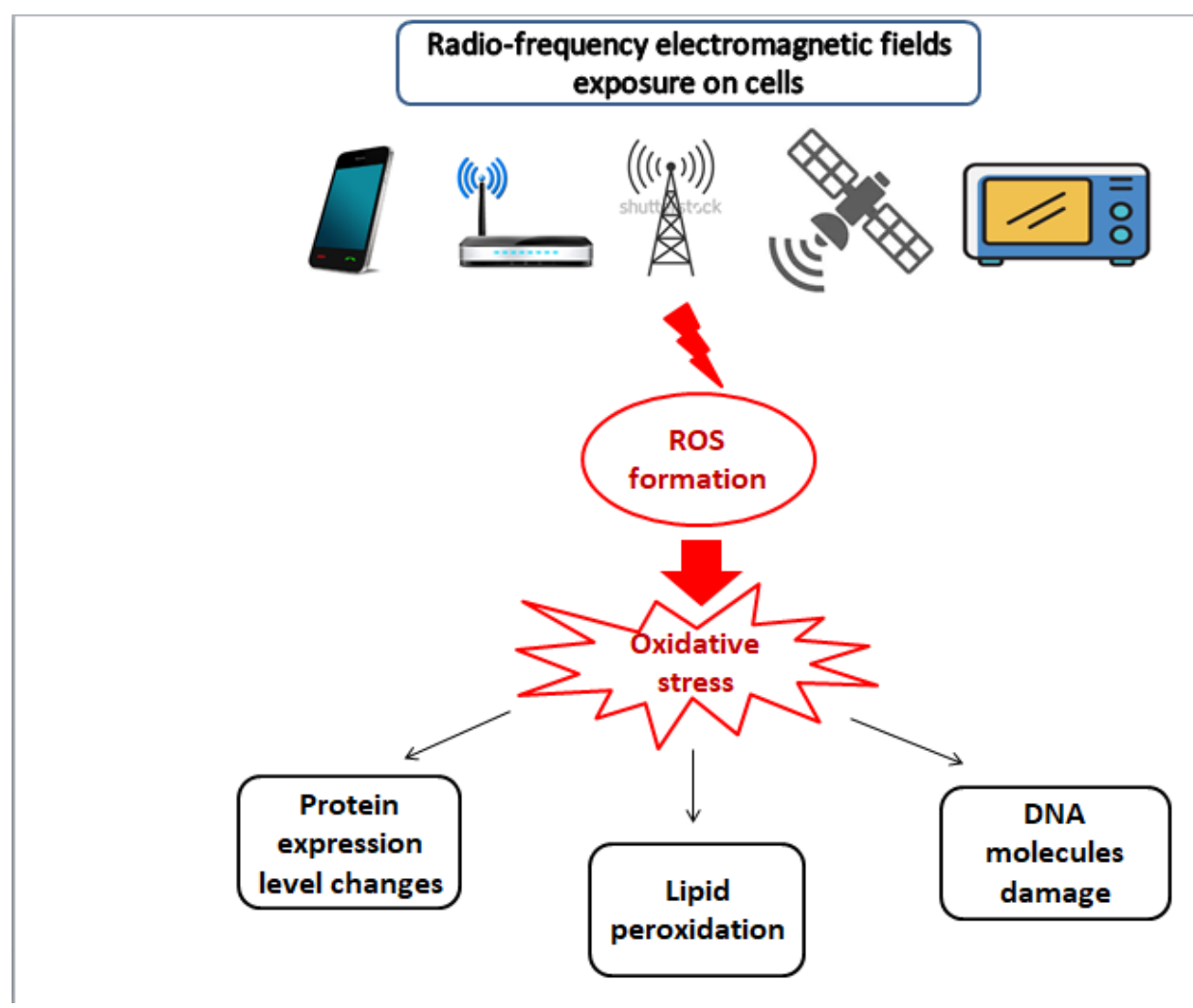

Fig. 1. Effects of RF-EMF on cells

There are several studies that have shown the effect of radio-EMF of different frequencies, exposure time and intensity on neuroglial cells of the brain [2]. The results of these studies show that exposure to $900 \mathrm{MHz}$ of RF fields on primary cultures of rat cortical neurons for 24 hours, with a specific absorption rate (SAR) of $2 \mathrm{~W} / \mathrm{kg}$, can induce apoptosis via a caspase-independent pathway [3].

Widely involved in neuronal apoptosis, apoptosis induction factor (AIF) is a mitochondrial inter-membrane flavoprotein that can induce caspase-independent peripheral chromatin condensation and DNA fragmentation [4]. AIF has been found to interact with several well-known pathways leading to neuronal apoptosis, including dopaminergic cell death in 
response to MPTP (1-methyl-4-phenyl-1,2,4,6-tetrahydropyridine) [5] in cortical neurons [6], beta-carboline-induced apoptosis in granules of cerebellar neurons [7], as well as VACdependent or -independent neuronal death [8]. AIF is also involved in the mechanism of excitotoxicity in cortical neurons and appears to inhibit the activity of PARP1 (poly (ADPribose) polymerase 1) in NMDA-mediated neuronal death [9], or in calpain 1 [10]. An in vivo translocation of AIF from mitochondria to the nucleus was found after brain injury in rodents [11].

There are also number of studies conducted on rat astrocytes. Since astrocytes respond to various stimuli and represent a valuable tool for studying biochemical mechanisms involved in some physiological and pathological conditions in the brain [12], the effects on primary neocortical astroglial cell cultures of rats after acute exposure to low-frequency EMF were evaluated.

As already mentioned, the increased production of reactive oxygen species (ROS) and DNA fragmentation induced by irradiation at $900 \mathrm{MHz}$ for 20 minutes cannot be attributed to thermal effects. The observed effects should be attributed to the amplitude modulation of the EMF. Indeed, exposure to unmodulated EMFs for 5, 10 and 20 minutes did not show any significant effect on astroglial cell cultures, while exposure to modulated EMFs for 20 minutes at the same power value resulted in clearly measurable effects.

Moreover, these data suggest that the elevated levels of ROS and DNA fragmentation induced by EM radiation may be associated with increased levels of intracellular calcium ions, possibly due to hyper stimulation of glutamate receptors, which play an important role in acute and chronic brain damage [13].

As it is known, ROS are one of the most important substances that explain the genotoxic effects of radio frequencies. The genotoxic effects that can be detected in cells and tissues after radiofrequency irradiation are easily explained by measuring ROS levels. Many studies have shown the effects of RF exposure on ROS production. For instance, rat's spiral ganglion neurons (SGN) were treated with lipopolysaccharide (LPS) to induce an inflammatory process in in vitro models before being exposed to $1800 \mathrm{MHz}$ radio frequencies for 24 hours. In the study, the following were studied: ROS production, DNA damage, ultra structural changes, and expression of Beclin 1 and LC3-II genes, which are the key proteins that regulate autophagy. As a result, no DNA damage or ultrastructural cellular changes were found in normal cells. Nevertheless, in the groups of LPS-induced and RF-irradiated cells, elevated ROS levels, the presence of lysosomes and autophagosomes, and increased expression of the Beclin 1 and LC3-II genes were observed. The sensitivity of SGN to radio frequencies suggests that interaction with LPS is the basis of the RF mechanism of action in the ROS system [14].

Zmyslony and others have also shown an increase in the level of chemically induced ROS in cell culture of rat lymphocytes exposed to RF-EMF at $930 \mathrm{MHz}$ and $1.5 \mathrm{~W} / \mathrm{kg}$ for 5 and 15 minutes, using $\mathrm{FeCl}_{2}$ as an ROS-inducing agent [15]. As a result, it was revealed that irradiation of cells at $930 \mathrm{MHz}$ at specific absorption rate (SAR) value at $1.5 \mathrm{~W} / \mathrm{kg}$ does not affect the amount of ROS produced. While adding $10 \mu \mathrm{g} / \mathrm{ml} \mathrm{of} \mathrm{FeCl}_{2}$ suspension showed the opposite effect. Fluorescence in lymphocytes treated with $\mathrm{FeCl}_{2}$ and irradiated with EMF was higher than in non-irradiated lymphocytes, by $16.6 \pm 7.7 \%$ after 5 minutes of irradiation, and $14.6 \pm 7.4 \%$ after 15 minutes of cell irradiation.

Yao et al., in a recent study, exposed human lens epithelial cells to $1.8 \mathrm{GHz}$ RF EMF for 2 hours and observed no effect in the group of low SAR value $(1 \mathrm{~W} / \mathrm{kg})$, while the higher SAR $(2,3$ or $4 \mathrm{~W} / \mathrm{kg})$ showed increased production of intracellular ROS [16].

However, the data are most contradictory at SAR $=2 \mathrm{~W} / \mathrm{kg}$, and some studies have shown RF irradiation effects at high SAR levels, but no effects at low SAR values.

Tice et al. found no effect of RF radiation on micronuclei at SAR values between 0 and 5 $\mathrm{W} / \mathrm{kg}$, while an increased number of micronuclei were recorded at SAR values from 5 to 10 $\mathrm{W} / \mathrm{kg}$ [17]. 
Lixia et al found that RF radiation did not affect the induction of DNA breaks at low SAR levels $(1$ or $2 \mathrm{~W} / \mathrm{kg}$ ), but higher SAR values $(3 \mathrm{~W} / \mathrm{kg}$ ) increased the number of DNA breaks within 30 minutes after exposure. [18]. Moreover, Mashevich et al reported that exposure to RF radiation increased the level of aneuploidy at SAR values of $2.6-3.5,4.0-4.8$, and $7.8-8.8$ $\mathrm{W} / \mathrm{kg}$, while no effect was found at low SAR values $(1.6-2.3 \mathrm{~W} / \mathrm{kg})$ [19].

While ROS production can damage macromolecules, increased DNA damage and increased ROS production can be interrelated. Similar results for DNA damage and ROS production were previously described by the Yao team, at SAR values of 3 and $4 \mathrm{~W} / \mathrm{kg}$, although in the absence of co-action of any agents [16].

In a study, genotoxic effects were investigated after irradiation of cell lines of murine spermatocytes with radio frequencies of GSM talk mode at $50 \mathrm{~Hz}$ for 24 hours. Alkaline DNA comet assay and immunofluorescence showed an increased number of double-strand DNA breaks in cells exposed to ultra-low electromagnetic irradiation, while no significant differences were found when cells were exposed to radio frequencies. DNA - formamidopyrimidine glycosylase (DFG) altered alkaline comet DNA analysis and radiofrequency increased oxidative DNA damage at SAR values of $4 \mathrm{~W} / \mathrm{kg}$, while exposure to ultralow frequencies did not show any significant differences. These results indicate that ultra-low frequencies and radio frequencies can create different DNA damage pathways and induce genotoxicity at relatively high intensities, due to their alternative potential mechanisms [20].

Hou et.al. investigated the effects of $1800 \mathrm{MHz}$ irradiation on mouse embryonic fibroblasts in order to detect ROS production, DNA damage, and apoptosis. The researchers found elevated levels of both intracellular ROS and the number of cells in the late apoptosis phase in groups of cells exposed to RF EMF for 1, 4 and 8 hours. However, the number of double-strand DNA breaks molecule was slightly increased in the groups exposed to RF for 2, 4, 6 and 8 hours compared to the control. These results again confirm the adverse effects of EMF in terms of ROS production [21].

As for the effects of EMF at the gene level, in one of the studies, the mutated gene Ataxia telangiectasia (Atm), which is the main protector of genomic stability, in fibroblasts of mouse embryos was studied in order to identify the genotoxic effect of radio frequency radiation at $1800 \mathrm{MHz}$. As a result of alkaline and neutral DNA comet assay, single and double stranded DNA breaks were identified. Increased levels of single- and double-strand breaks have been identified in Atm-deficient embryonic fibroblasts from mice exposed to $1800 \mathrm{MHz}$ RF EMF. Additionally, increased phosphorylation and expression of X-ray cross-complementary protein 1 (CSCP1) in groups with high and insufficient ATM content, which is critical in the mechanisms of DNA damage repair. The activation of DNA repair mechanisms showed that $1800 \mathrm{MHz}$ radio frequencies increased the level of DNA damage and damaged cellular homeostasis [22].

Earlier in vitro studies on influence of RF EMF have mainly focused on the toxic effect of RF on cells. Some of these have focused on the intracellular mechanisms that support the induction of DNA damage and cell death. For example, Bourthoumieu has demonstrated a genotoxic effect on amniotic cells exposed to $900 \mathrm{MHz}$ GSM radiation for 24 hours [23]. As a result, no cytogenic effect was observed after irradiation. Increased dosage over a wider range of SAR values (up to $4 \mathrm{~W} / \mathrm{kg}$ ) and similar experiments showed that irradiation did not affect the intracellular stress-related p53 pathway. p53 Is an important checkpoint system that protects against genomic instability by inducing cell cycle arrest and apoptosis. Previous data on shortterm irradiation at $900 \mathrm{MHz}$ of lymphoblastic leukemia cells showed activation of pathways associated with p53.

In addition, Akhavan-Sigari and co-authors reported a relationship between increased expression of the mutant p53 gene in the peripheral zone of tumors and EMF irradiation from mobile phones (1800 MHz) exceeding 3 hours per day [24].

However, prolonged continuous exposure resulted in the silencing of pro-apoptotic signals and activation of genes such as Bcl-2, Ras and Aktl. This dual effect can be consistent with an early self-defense mechanism triggered after DNA damage [25]. The authors reported 
genotoxic damage and changes in gene expression levels. To fully understand the response of lymphoblastic leukemia cells to RF exposure, studies were conducted by analyzing microarrays on cancer cells. Trivino Pardo and colleagues have confirmed that high-frequency EMFs affect cellular systems by acting as genotoxic agents [26]. Significant changes in the expression levels of genes involved in DNA repair, cell cycle delay, apoptosis, chromosomal organization, and angiogenesis were detected after short- and long-term EMF irradiation at $900 \mathrm{MHz}$. It was revealed that the DNA repair mechanism was subjected to a double effect with the activation of p53-associated genes and the suppression of down-strain effectors such as BRCA2, XRCC3, and RFC1. Apoptosis signals were affected by RF irradiation, as APAF1 was overexpressed with suppression of FASL, which initiates a non-apoptotic survival signal, and CASP8, which regulates apoptosis modulation and signaling. An increased regulation in the early period of another component of the "caspase" cascade, CASP10, was also revealed. Thus, RF, acting as a genotoxic agent, induces DNA damage by activating early effectors of cell death in the apoptotic response.

Considering the aggressiveness of tumor cells, changes in the expression of genes involved in the regulation of angiogenesis, differentiation and regulation of the cytoskeleton were detected. Also, down regulation of BAI1 and TNFSF15 was found in genes involved in the regulation of angiogenesis signals. Likewise, exposure to microwave EMFs inhibited VEGFA, which plays a significant role in cell permeability, and FLT4 involved in lympho-angiogenesis. At the same time, EPO, IL8, STAT5B and VAV2, PGF, HPSE were overly activated. Thus, it is likely that microwave EMFs can act as dual negatively targeted gene regulators in lymphoblastic leukemia cells: they affect the control of chromosomal organization and induce angiogenesis, which in turn leads to tumor progression and metastatic transformation. It should also be noted that several previous microarray analyzes performed after RF exposure did not reveal any significant changes in gene expression in normal peripheral or glial cells of the central nervous system (CNS) [26], as well as in cancer models. Moreover, these authors suggested that disruptions in hydrogen bonds may play a significant role in maintaining changes in the protein profile of cells after RF exposure to determine their bioeffects.

Elements of cellular architecture, such as membranes or cytoskeleton, can be considered as possible targets for damage after EMF exposure. In 2004, the REFLEX study, Quality of Life and Living Resources Management, funded by the European Union to assess the risk of potential environmental threats to EMF exposures in vitro, stated that RF EMF increased microtube damage and DNA strand breaks in HL-60 cells. Microtubes are macromolecular structures composed of tubulin heterodimers and are present in almost every eukaryotic cell. It was shown that exposure to a frequency of $900 \mathrm{MHz}$ interferes with the in vitro polymerization process in changing the structure of microtubes [27].

Effects of RF EMF in vivo. In vivo studies are very important as protocols can be designed to apply a thorough and controlled exposure procedure over a longer period of time, with an understanding of chronic exposure that more accurately predicts the degree of risk to human health. Selected in vivo models are used to address specific scientific questions. For example, Eisenia Fetida (Oligochaeta, worm) are selected for standardized analysis for risk assessment in terrestrial ecosystems [28]. This model has been validated to study the toxicological endpoints of genotoxicity, such as DNA damage, antioxidant enzyme activity, and lipid peroxidation. Damage to proteins, fats and DNA was found after 2 hours of exposure to 900 $\mathrm{MHz}$ EMF at a specific power of $23 \mathrm{Wm}-1$.

Another readily amenable in vivo model for the study of DNA fragmentation is Drosophila melanogaster. The reproductive ability of Drosophila melanogaster after $900 \mathrm{MHz}$ irradiation was studied [29]. As a result of this study, significant decrease in the reproductive capacity of insects was shown. The decrease was associated with an increase in the percentage of induced DNA fragmentation and changes in the actin-cytoskeletal network of the egg chambers. 
Rodent models are widely used to study the effects of RF EMF on the morphology, biology, and function of mammalian brains and their neural networks. In 2011, Ntzouni et al. [30] conducted a study to examine the effects of mobile phones on short-term memory. Time is an important factor in the ultimate outcome in memory formation. It was found that RF exposure immediately after passing a test on the ability to judge a previously discovered object deeply affects the formation of memory. One of the most important subcortical regions of the CNS in relation to the formation and storage of memory is the hippocampus. Pyramidal cells are the architectural and functional units of the Cornus Ammonis and the dentate gyrus. Excitation in these cells is regulated by intra- and extracellular calcium homeostasis. RF exposure at $835 \mathrm{MHz}$ (SAR value $1.6 \mathrm{~W} / \mathrm{kg}$ ) affected calbindin and calretinin, causing a progressive loss of pyramidal cells in mice irradiated for three hours [31].

Moreover, Ammari et al. [32] previously indicated that the metabolic functions of cytochrome $\mathrm{C}$ oxidase in the brain, and in particular in the peririnal and entorhinal cortex, were affected by radio irradiation with a frequency of $900 \mathrm{MHz}$ and $\mathrm{SAR}=6 \mathrm{~W} / \mathrm{kg}$, while disrupting memory formation. From this perspective, it is striking how little research has been done on the effects of RF on neurotransmitters. Neurotransmitters such as serotonin (5HT) and dopamine orderly regulate the acquisition, formation and storage of memory in specific areas of the brain. After four months of daily RF exposure (1800 MHz, SAR $0.843 \mathrm{~W} / \mathrm{kg}$ ), adult rats exhibited increased serotonin levels and decreased hippocampal dopamine levels, which affected memory and learning ability.

Maskey [31] suggested that repeated five-hour sessions of daily $835 \mathrm{MHz}$ exposure of rats $(\mathrm{SAR}=1.6 \mathrm{~W} / \mathrm{kg})$ could alter the permeability of the cell membrane of pyramidal cells of the hippocampus, thus compromising neural connection.

The involvement of radiofrequencies in some neuropathologies is now widely discussed. Among neurodegenerative diseases, Alzheimer's disease (AD) has long been associated with RF EMF. In fact, Alzheimer's disease is characterized by the presence of morphological (neurofibrillary tangles and $\beta$-amyloid deposition in cortical and hippocampal neurons) and functional (changes in memory and behavior) biomarkers. One of the corresponding characteristics of AD is most likely an increased production of ROS and associated inflammation of the cortical and subcortical tissues of the brain affected by AD. There are many reports that an increase in ROS levels in the brain after RF exposure [33] promotes an increase in cascade molecular events, including the activity of antioxidant enzymes, protein kinase $\mathrm{C}$, creatine kinase, and pro-apoptotic enzyme caspase-3. RF-dependent expression of reactive astroglia has also been identified [32]. Apparently, there is a causal relationship between the development of $\mathrm{AD}$ and RF radiation; however, there are very few studies suggesting the effect of RF exposure on this pathology.

It has been demonstrated that chronic pulsed RF exposure can reverse both $\beta$-amyloid deposition and amelioration of cognitive deficits in mice [33].

Similar effect was obtained in both wild and mutated mice [34], where RF EMF increased mitochondrial activity and decreased cerebral blood fluid levels, thus facilitating the removal of $\beta$ - amyloid from the CNS regions. Banaceur and colleagues received interesting data. They drew attention to another aspect, which is not yet fully understood and related to WiFi radio waves $(2.40 \mathrm{GHz}, \mathrm{SAR}=1.6 \mathrm{~W} / \mathrm{kg}) .3 \times \mathrm{Tg}-\mathrm{AD}$ transgenic mice were exposed to $\mathrm{RF}$ EMF for 28 consecutive days and tested for cognitive and behavioral responses [35]. It turned out that exposure to Wi-Fi can positively affect cognitive function and anxiety. The authors investigated the molecular pathways underlying these results.

There are also several reports regarding Parkinson's disease (PD) and RF exposure. PD is another neurodegenerative disease that is caused by the degeneration of dopaminergic neurons in the Substantia Nigra of the midbrain. A possible connection between radio frequencies and BP has been suggested [36]. Dopamine expression and the expression of enzymes that are involved in its metabolism, such as monoanioxidases (MAO), have also been investigated after RF radiation in rats [37]. Moreover, abnormal aggregation of $\alpha$-synuclein plays a decisive role in the 
pathogenesis of PD and its toxicity. The physiological function of $\alpha$-synuclein remains unspecified. Nevertheless, the deposition of the $\alpha$-synuclein protein in Lewy bodies is considered a biomarker of PD, since its accumulation, even in small amounts, can be a risk factor for the development of neurodegeneration.

Decreased expression of $\alpha$-synuclein was revealed after acute exposure to $900 \mathrm{MHz} \mathrm{EMF}$ in cultured mixed cortical cultures of rat embryonic brain cells [38].

Long-term whole-body irradiation of Balb/c mice showed changes in protein expression in the cerebellum, hippocampus, and frontal lobe. The expression of $\alpha$-synuclein has been shown to be altered along with the expression of glial fibrillar acidic protein (GFAP), glial maturation factor beta (FSH) and apolipoprotein $\mathrm{E}$ (apoE), indicating impaired neuronal plasticity. Moreover, heat shock proteins and cytoskeletal proteins also varied significantly, suggesting possible structural and morphological changes in RF-irradiated brain [39].

The actual effects of RF EMF exposure on the induction and development of PD remain uncertain. Several studies on the impact of RF radiation on the permeability of the neural bloodbrain barrier should be noted. The blood-brain barrier (BBB) is a defense mechanism that regulates molecular exchanges between blood circulation and neural tissues [40]. Changes in the permeability of the barrier can occur due to pathologies or trauma, such as a stroke. BBB permeability can also be temporarily increased due to pulsed low-frequency EM radiation [41].

A full seven-day irradiation of rats with GSM $900 \mathrm{MHz}$ for 2 hours daily (SAR up to 14 $\mathrm{mW} / \mathrm{kg}$ ) showed an increase in the BBB permeability, which lasted up to 14 days of treatment. Moreover, there was no loss of neurons with these EMF settings [42]. Although the temporary opening of the BBB can be used for therapeutic purposes, the benefit/risk balance of EMF should be carefully monitored. Concerns about the potential negative effects of RF on the developing brain still exist [43].

Brain development in mammals depends on time and growth factors, and is highly susceptible to external damage that could jeopardize future network functions. It was shown that pre- and postnatal exposure to RF EMF of mobile phones on rat embryos provoked an increase in the level of neurodegeneration of Purkinje cells in the cerebellum of rats, assessed in adulthood. But lycopene (a natural antioxidant) - enriched diet partially prevented cases of neurodegeneration with a caspase 3 - dependent apoptotic cascade. Although there was no specific timing, these results are impressive and disturbing enough when scaled to human conditions. Equally remarkable is the effect of prolonged $900 \mathrm{MHz}$ RF irradiation on young rats, which were found to be more susceptible to oxidative stress metabolism measured in peripheral tissues and blood. This effect is likely due to altered blood levels of glutathione (GT). Likewise, an in vitro study of bone marrow cell culture in mature rats showed that cytogenetic damage was more significant than in adult rats [44].

The US National Toxicology Program in 2016 published a long-term bioanalysis of animals, which examined the level of exposure to mobile phone radiation equivalent to that which people are currently exposed to in everyday life. They found that rats exposed to mobile phones radiation had a higher incidence of brain tumors. They also found out unusual pathways and significant rates of malignant neoplasms in the nerve leading to the heart. Epidemiological studies have in fact revealed increased rates of brain cancers and acoustic neuroma [45].

\section{CONCLUSION}

It has now been established that EMF can lead to harmful effects through damage to structures and breaks in DNA molecule, as well as through oxidative stress. For very short durations and low frequencies, non-ionizing RF radiation may not have any harmful effects. However, the average person living in a city is continuously exposed to non-ionizing radio frequency EMF throughout the day in various ways. Long-term exposure can lead to an increase in ROS production and create indirect negative effects. 
It is almost impossible to take into account all the potential situations in which we are faced with accidental or expected exposure to EMF in our daily life. Moreover, it is rather difficult to describe the variable interactions between RF EMF and biological systems. It can be assumed that EMF has a different effect on each organism and on each cell. EMF can potentially induce protein modification, ion exchange, and conformational changes in nucleic acids, which in turn lead to positive, adaptive, or destructive effects, and EMF modulation can determine the benefit or severity of the results.

Nowadays, ever higher EMF frequencies have been used. And due to the increased development of mobile telephony and Wi-Fi technologies, the number of studies has increased to identify the potential negative (including carcinogenic) effects of EM irradiation on living organisms, including humans. A large number of studies conducted, however, have not shown any relationship between exposure to EMF and an increased risk of developing malignant tumors.

In vitro and in vivo studies are more revealing and their results are significantly reliable. The effects of EMF can be shown using a large number of samples under standardized laboratory conditions. The ability to test the observed effects, study the mechanisms of EMF action, and test hypotheses makes the results of experimental studies very valuable.

We tried to review the latest advances in understanding the nature and possible functional impact of the effects associated with exposure to radio frequency EMF on cells and animals.

And to conclude, we can say that in the light of the information collected in this review, EMF shows its biological effects by indirectly affecting cellular structures. Long-term disruption of homeostasis can lead to the devastating effects of EMF. The safety of EMF has not been clearly demonstrated and therefore the necessary precautions must be taken to ensure the health and safety of the population.

In addition, one should not forget that EMF is energy and can exhibit the effects of accelerating entropy on every object present in the environment. There is no clear evidence for the safety of EMFs and therefore the necessary precautions must be taken to ensure public health and safety.

\section{Acknowledgements}

This work was supported by the Ministry of Education and Science of the Republic of Kazakhstan (grant AP05133910 «Bio-effects of Electromagnetic Radiation from Mobile Phones and Wi-Fi on DNA of brain cells»).

\section{REFERENCES}

1. Andrzej Magiera, Jolanta Solecka. Mobile telephony and its effects on human health. Rocz Panstw Zakl Hig, 2019, vol. 70, no.3, pp. 225-234.

2. Ju Hwan Kim,1 Jin-Koo Lee,1 Hyung-Gun Kim, et.al. Possible Effects of Radiofrequency Electromagnetic Field Exposure on Central Nerve System. Biomol Ther (Seoul), 2019, vol. 27, no.3, pp. 265-275.

3. Diem E., Schwarz C., Adlkofer F. et.al. Non-thermal DANN breakage by mobilephone radiation $(1800 \mathrm{MHz})$ in human fibroblasts and in transformed GFSH-R17 rat granulosa cells in vitro. Mutat. Res., 2005, vol. 583, pp. 178-183.

4. Joubert V., Bourthoumieu S., Leveque P. et.al. Apoptosis is induced by radiofrequency fields through the caspase-independent mitochondrial pathway in cortical neurons. Radiat. Res., 2008, vol. 169, pp. 38-45.

5. Nakamura H., Matsuzaki I., Hatta K. et.al. Non-thermal effects of mobile-phone frequency microwaves on uteroplacental functions in pregnant rats. Reprod. Toxicol., 2003, vol. 17, pp. 321-326. 
6. Joubert V., Bourthoumieu S., Leveque Ph., et.al. Apoptosis is induced by Radiofrequency Fields through the Caspase-Independent Mitochondrial Pathway in Cortical neurons. Radiation Research, 2008, vol. 169, no.1, pp. 38-45.

7. Cregan S. P., Fortin A., MacLaurin J. G. et.al. Apoptosis-inducing factor is involved in the regulation of caspaseindependent neuronal cell death. J. Cell Biol., 2002, vol. 158, pp. 507-517.

8. Liou A.K., Zhou Z., Pei W. et.al. BimEL up-regulation potentiates AIF translocation and cell death in response to MPTP. FASEB J., 2005, vol. 19, pp. 1350-1352.

9. Stoica B.A., Movsesyan V.A., Knoblach S.M. et.al. Ceramide induces neuronal apoptosis through mitogen-activated protein kinases and causes release of multiple mitochondrial proteins. Mol. Cell Neurosci., 2005, vol 29, pp. 355-371.

10. Hans G., Malgrange B., Lallemend F., et.al. Beta-carbolines induce apoptosis in cultured cerebellar granule neurons via mitochondrial pathway. Neuropharmacology, 2005, vol. 48, pp. 105-117.

11. Cheung E.C., Melanson-Drapeau L., Cregan S.P., et.al. Apoptosis-inducing factor is a key factor in neuronal cell death propagated by BAX-dependent and BAX-independent mechanisms. J. Neurosci., 2005, vol. 25, pp. 1324-1334.

12. Wang H., Yu S.W., Koh D.W., et.al. Apoptosisinducing factor substitutes for caspase executioners in NMDA-triggered excitotoxic neuronal death. J. Neurosci., 2004, vol. 24, pp. 10963-10973.

13. Plesnila N., Zhu C., Culmsee C., et.al. Nuclear translocation of apoptosis-inducing factor after focal cerebral ischemia. J. Cereb. Blood Flow Metab., 2004, vol. 24, pp. 458-466.

14. Campisi A., Caccamo D., Raciti G. et.al. Glutamate-induced increases in transglutaminase activity in primary cultures of astroglial cells, Brain Res., 2003, vol. 978, pp. 24-30.

15. Zmyslony M., Politanski P., Rajkowska E., et.al. Acute exposure to $930 \mathrm{MHz}$ CWelectromagnetic radiation in vitro affects reactive oxygen species level in rat lymphocytes treated by iron ions. Bioelectromagnetics, 2004, vol. 25, pp. 324-328.

16. Yao K., Wu W., Wang K., et.al. Electromagnetic noise inhibits radiofrequency radiation-induced DNA damage and reactive oxygen species increase in human lens epithelial cells. Mol. Vis., 2008, vol. 14, pp. 964-969.

17. Tice R.R., Hook G.G., Donner M., et.al. Genotoxicity of radiofrequency signals. I. Investigation of DNA damage and micronuclei induction in cultured human blood cells. Bioelectromagnetics, 2002, vol. 23, pp. 113-126.

18. Lixia S., Yao K., Kaijun W. et.al. Effects of $1.8 \mathrm{GHz}$ radiofrequency field on DNA damage and expression of heat shock protein 70 in human lens epithelial cells. Mutat. Res., 2006, vol. 602, pp. 135-142.

19. Mashevich M., Folkman D., Kesar A. et.al. Exposure of human peripheral blood lymphocytes to electromagnetic fields associated with cellular phones leads to chromosomal instability. Bioelectromagnetics, 2003, vol. 24, pp. 82-90.

20. Duan W., Liu C., Zhang L., et.al. Comparison of the genotoxic effects induced by 50 $\mathrm{hz}$ extremely low-frequency electromagnetic fields and $1800 \mathrm{mhz}$ radiofrequency electromagnetic fields in gc-2 cells. Radiat. Res., 2015, vol. 183, pp. 305-314.

21. Hou Q., Wang M., Wu S., et.al. Oxidative changes and apoptosis induced by 1800$\mathrm{MHz}$ electromagnetic radiation in NIH/3t3 cells. Electromagn. Biol. Med., 2015, vol. 34, pp. 85-92.

22. Sun C., Wei X., Fei Y., et.al. Mobile phone signal exposure triggers a hormesis-like effect in Atm+/+ and Atm-/- mouse embryonic fibroblasts. Sci. Rep., 2016, vol. 6, pp. 37423. 
23. Bourthoumieu S., Joubert V., Marin B. et.al. Cytogenetic studies in human cells exposed in vitro to GSM-900 MHz radiofrequency radiation using R-banded karyotyping. Radiat. Res. 2010, vol. 174, pp. 712-718.

24. Akhavan-Sigari R., Mazloum F.B.M., Ariabod V., et.al. Connection between cell phone use, p53 gene expression in different zones of glioblastoma multiforme and survival prognoses. Rare Tumors, 2016, vol. 6, pp. 5350.

25. Lu Y.S., Huang B.T., Huang, Y.X. Reactive oxygen species formation and apoptosis in human peripheral blood mononuclear cell induced by $900 \mathrm{MHz}$ mobile phone radiation. Oxid. Med. Cell. Longev. 2012, vol. 2012, pp. 740280.

26. Trivino Pardo J.C., Grimaldi S., Taranta M., Naldi I. et.al. Microwave electromagnetic field regulates gene expression in T-lymphoblastoid leukemia CCRF-CEM cell line exposed to $900 \mathrm{MHz}$. Electromagn. Biol. Med., 2012, vol. 31, pp. 1-18.

27. Roux D., Girard S., Paladian F., et.al. Human keratinocytes in culture exhibit no response when exposed to short duration, low amplitude, high frequency $(900 \mathrm{MHz})$ electromagnetic fields in a reverberation chamber. Bioelectromagnetics, 2011, vol. 32, pp. 302-311.

28. Tkalec M., Stambuk A., Srut M. et.al. Oxidative and genotoxic effects of $900 \mathrm{MHz}$ electromagnetic fields in the earthworm Eisenia fetida. Ecotoxicol. Environ. Saf., 2013, vol. 90, pp. 7-12.

29. Consales C., Merla C., Marino C. et.al. Electromagnetic fields, oxidative stress, and neurodegeneration. Int. J. Cell Biol., 2012, vol. 2012, pp. 683897.

30. Ntzouni M.P., Stamatakis A., Stylianopoulou F., et.al. Short-term memory in mice is affected by mobile phone radiation. Pathophysiology, 2011, vol. 18, pp. 193-199.

31. Maskey D., Pradhan J., Aryal B. et.al. Chronic 835-MHz radiofrequency exposure to mice hippocampus alters the distribution of calbindin and GFAP immunoreactivity. Brain Res., 2010, vol. 1346, pp. 237-246.

32. Ammari, M.; Lecomte, A.; Sakly, M.; et.al. Exposure to GSM $900 \mathrm{MHz}$ electromagnetic fields affects cerebral cytochrome c oxidase activity. Toxicology, 2008, vol. 250, pp. 70-74.

33. Jiang D.P., Li J., Zhang, J. et.al. Electromagnetic pulse exposure induces overexpression of beta amyloid protein in rats. Arch. Med. Res., 2013, vol. 44, pp. 178184.

34. Dragicevic N., Bradshaw P.C., Mamcarz M. et.al. Long-term electromagnetic field treatment enhances brain mitochondrial function of both Alzheimer's transgenic mice and normal mice: A mechanism for electromagnetic field-induced cognitive benefit? Neuroscience, 2011, vol. 185, pp. 135-149.

35. Banaceur S., Banasr S., Sakly M., et.al. Whole body exposure to $2.4 \mathrm{GHz}$ WIFI signals: Effects on cognitive impairment in adult triple transgenic mouse models of Alzheimer's disease (3× Tg-AD). Behav. Brain Res., 2013, vol. 240, pp. 197-201.

36. Filali M., Lalonde R., Theriault P. et.al. Cognitive and non-cognitive behaviors in the triple transgenic mouse model of Alzheimer's disease expressing mutated APP, PS1, and Mapt (3× Tg-AD). Behav. Brain Res., 2012, vol. 234, pp. 334-342.

37. Carpenter D.O. Human disease resulting from exposure to electromagnetic fields1). Rev. Environ. Health, 2013, vol. 28, pp. 159-172.

38. Terro F., Magnaudeix A., Crochetet, M., et.al. GSM-900MHz at low dose temperaturedependently downregulates alpha-synuclein in cultured cerebral cells independently of chaperone-mediated-autophagy. Toxicology, 2012, vol. 292, pp. 136-144.

39. Fragopoulou A.F., Samara A., Antonelou M.H., et al. Brain proteome response following whole body exposure of mice to mobile phone or wireless DECT base radiation. Electromagn. Biol. Med., 2012, vol. 31, pp. 250-274. 
40. Li H.J., Guo L.M., Yang L.L., et.al. Electromagnetic-pulse-induced activation of p38 MAPK pathway and disruption of blood-retinal barrier. Toxicol. Lett., 2013, vol. 220, pp. 35-43.

41. Zhou J.X., Ding G.R., Zhang J., et.al. Detrimental effect of electromagnetic pulse exposure on permeability of in vitro blood-brain-barrier model. Biomed. Environ. Sci., 2013, vol. 26, pp. 128-137.

42. Nittby H., Brun A., Eberhardt J., et.al. Increased blood-brain barrier permeability in mammalian brain 7 days after exposure to the radiation from a GSM-900 mobile phone. Pathophysiology, 2009, vol. 16, pp. 103-112.

43. Pelletier A., Delanaud S., Decima P., et.al. Effects of chronic exposure to radiofrequency electromagnetic fields on energy balance in developing rats. Environ. Sci. Pollut. Res. Int., 2013, vol. 20, pp. 2735-2746.

44. Aydin B., Akar A. Effects of a $900-\mathrm{MHz}$ electromagnetic field on oxidative stress parameters in rat lymphoid organs, polymorphonuclear leukocytes and plasma. Arch. Med. Res., 2011, vol. 42, pp. 261-267.

45. Sekeroglu V., Akar A., Sekeroglu Z.A. Cytotoxic and genotoxic effects of highfrequency electromagnetic fields (GSM $1800 \mathrm{MHz}$ ) on immature and mature rats. Ecotoxicol. Environ. Saf., 2012, vol. 80, pp. 140-144.

\title{
РАДИОЖИІЛІКТІ ЭЛЕКТРОМАГНИТТІК ӨРІСТЕРДІН IN VITRO ЖӘНЕ IN VIVO ӘСЕРЛЕРI
}

\author{
Бегимбетова Д. А. ${ }^{1}$, Байсханова Д. М. ${ }^{1}$, Маткаримов Б. Т. ${ }^{2}$, Шульгау 3. Т. \\ ${ }^{1}$ Трансляциялық Медицина және Өмір Тураль Ғылымдар Зертханасы, National \\ Laboratory Astana, Назарбаев Университеті \\ Қабанбай батыр данувыльы, 53, Нұр-Сұлтан, 010000. \\ ${ }^{2}$ Биосенсорлар және Биоинструменттер Зертханасы, National Laboratory Astana, \\ Назарбаев Университеті. \\ Қабанбай батыр данувыльы, 53, Нұр-Сұлтан, 010000. \\ 3 Ұлттық Биотехнология Opтальгы \\ Қоргалжын тас жоль, 13/5, Нұр-Сұлтан, 010000. \\ d.baiskhanova@nu.edu.kz
}

\section{АБСТРАКТ}

Соңғы жылдары ұялы телефондар мен Wi-Fi желілері қолданыста жаппай көбейіп келеді. Осыған орай олардың тірі ағзаларға, соның ішінде адамға тигізетін әсеріне қатысты алаңдаушылық күшейді. Ұялы телефондар мен Wi-Fi желілері шығаратын радиожиілікті электромагниттік өрістердің қысқа мерзімді әсерінің зиянды әсерінің болмауы туралы ертерек жасалған болжамдарға қарамастан, қазіргі кезде электромагниттік өрістердің адам ағзасына тотығу стрессі мен ДНК құрылымының зақымдануы арқылы зиянды әсер етуінің дәлелдері артып отыр. Электромагниттік өрістердің ұзақ уақыт әсер етуі адам ағзасындағы әртүрлі патологиялық жағдайлардың дамуына, соның ішінде онкологиялық ауруларға, когнитивті функциялар мен ұйқының бұзылуына және т.б. ауытпашылыққа алып келеді.

Бұл шолу түріндегі мақалада радиоэлектрлік электромагниттік өрістің адам мен жануарлар жасушаларына әртүрлі жағымсыз әсерлерін көрсететін қолданыстағы зерттеулер талданады және жинақталады. 
Электромагниттік өрістердің адам ағзасына әсері туралы көптеген қарамақайшылықты мәліметтер болғандықтан, бұдан кейінгі зерттеулер ғана ұялы телефондар мен Wi-Fi желілерінің жағымсыз әсеріне жауап бере алады.

Негізгі сөздер: электромагниттік өріс, әсерлер, in vitro, in vivo, радиожиілік, апоптоз, ДНК зақымдануы

\title{
IN VITRO И IN VIVO ЭФФЕКТЫ РАДИО-ЧАСТОТНЫХ ЭЛЕКТРОМАГНИТНЫХ ПОЛЕЙ
}

\author{
Бегимбетова Д. А. ${ }^{1}$, Байсханова Д. М. ${ }^{1}$, Маткаримов Б. Т. ${ }^{2}$, Шульгау 3. Т. ${ }^{3}$ \\ 1 Лаборатория трансляциионной медицины и технологий наук о жизни, National \\ Laboratory Astana, Назарбаев Университет \\ пр. Кабанбай батыра, 53, г. Нур-Султан, 010000. \\ 2 Лаборатория биосенсоров и биоинструментов, National Laboratory Astana, \\ Назарбаев Университет \\ пр.Кабанбай батыра, 53, г. Нур-Султан, 010000. \\ ${ }^{3}$ Национальный центтр биотехнологии \\ Кургальжинское шоссе, 13/5, Нур-Султан, 010000. \\ d.baiskhanova@nu.edu.kz
}

\section{АБСТРАКТ}

В последние годы наблюдается массовое распространение мобильных телефонов и Wi-Fi сетей. В связи с этим возникают опасения по поводу опасности их воздействия на живые организмы, включая человека. Несмотря на более ранние предположения об отсутствии вредных эффектов кратковременного воздействия радиочастотных электромагнитных полей, излучаемых мобильными телефонами и Wi-Fi сетями, в настоящее время все большее распространение получают данные, указывающие на потенциально опасное воздействие электромагнитных полей на организм человека путем индукции окислительного стресса и повреждения структуры ДНК. Предполагается, что длительное воздействие электромагнитными полями может вызывать развитие различных патологических состояний в человеческом организме, включая онкологические заболевания, нарушение когнитивных функций и сна, и т.д.

В данном обзоре проведен анализ и обобщение существующих исследований, указывающих на различные негативные эффекты радиочастотных электромагнитных полей, на клетки человека и животных. Так как существует большое количество противоречивых данных о влиянии электромагнитных полей на организм человека, только дальнейшие исследования могут дать ответ на возможные негативные эффекты мобильных телефонов и Wi-Fi сетей.

Ключевые слова: электромагнитное поле, эффекты, in vitro, in vivo, радиочастоты, апоптоз, повреждения ДНК. 